\title{
What Teachers Think and Students Know ${ }^{1}$
}

\section{- Expanding the view of media literacy in religious education}

\begin{abstract}
In Sweden, media in various forms act as one of the main settings where young people encounter religion, both in schools and elsewhere. With a seemingly ever-expanding development of communication technology, researchers and politicians alike are arguing for the need to educate our citizens in media literacy. By applying the concept of multiple media literacy, this article argues for a more nuanced view of the skills needed to critically engage with various kinds of media. By analysing interview material of both teachers and students, the article concludes that increased focus within $R E$ on how various mediums operate, and on the complex nature of social media, would likely result in a richer media literacy for students and teachers alike.
\end{abstract}

Keywords: multiple media literacy; mediatization; pupil perspectives; religious studies

MaXimilian BRoberg, Department of Theology, Uppsala Religion and Society Research Centre, Uppsala University.E-mail: Maximilian.broberg@crs.uu.se

ANNA WRAMMERT, Department of Theology, Uppsala University

Address: Uppsala Religion and Society Research Centre, Faculty of Theology, Uppsala University, Box 511, SE-751 20 Uppsala, Sweden

\section{INTRODUCTION}

In recent years, Swedish teachers and students of religious education (RE) have had to adapt to the increased digitalization and media-saturation of society, and several studies have shown that this brings new challenges and dynamics to RE classrooms (Broberg, 2019; Lied \& Toft, 2018; Toft, 2019). A consequence of this development is that media materials such as news articles and documentaries, and media discourses like the link between Islam and terrorism, have become integrated parts in the teaching and learning about religion in Swedish schools (Toft \& Broberg, 2018). Among other things, this calls for new competencies among teachers and students regarding the conception of, and engagement with, mediated religion in various forms. By comparing material from two separate

1 Acknowledgments: Part of this study was supported by the Swedish Research Council (VR) under grant number 721-2013-2318. The Regional Ethics Review Board in Uppsala has approved both included projects in their entirety. Disclosure statement: No potential conflict of interest is reported by the authors.

Prismet - IKO-Forlaget 2020

Tilgjengelig på https://journals.uio.no/index.php/prismet. Publisert under CC BY-NC 4.0. Fagfellevurdert

Årgang 71, hefte 1, s. 59-74 
studies that focus on teachers and students respectively, the aim of this study is to explore and nuance some of these competencies.

In this endeavour, the material will be viewed through the theoretical lens of media literacy (Potter 2016), and the analysis will be based on an operationalization of Joshua Meyrowitz's concept of multiple media literacy (1998) in order to explore and nuance the kinds of media literacy the teachers and students in the material display. The primary focus will be on the differences in the material, as discrepancies in the understanding of various media is a likely cause of didactic dilemmas in the classroom.

\section{BACKGROUND}

In 2010, Robert Jackson and his colleagues declared that with the increased presence of web-based resources in the classroom, both teachers and students have to become 'critical evaluators' of such materials (Jackson et al., 2010, p. 4). During the past decade, both academic and practical attention have been given to address this topic, broadly labelled 'media literacy' (for a research review, see for example McDougall et al. 2018). A common backdrop for such research is the urgent need to combat 'fake news', and that teachers, but especially students, must learn how to separate between reliable and unreliable sources, especially on the internet.

However, according to media scholar Joshua Meyrowitz (1998), the kind of media literacy that concerns different kinds of evaluation of media content (reliability, political or economic motives etcetera) is just one of several kinds of media literacy. Furthermore, previous research indicates that young people in Sweden are actually quite literate when it comes to media content, and just as the population in general, they tend to trust established 'old media' over other news sources, such as social media (Nygren \& Bronéus, 2018). Instead, with a harsher and more polarised political climate spreading in Sweden, who and what is considered trustworthy seems to have become a question of personal preference, and varies more over the political spectrum than it does between age-groups (Nordicom - Sweden's Media Barometer 2018).

Relevant to this study's scope is what kind of media materials RE teachers use in their teaching, and what criteria they use in the selection. In the project Teaching Religion in Late Modern Sweden (TRILS), RE teachers were surveyed and interviewed about their own and their students' use, and views, of various media. The survey showed that the materials RE teachers report using are, in falling order; textbooks, images, documentaries, sacred texts, television news, and news articles, and to a much lower extent; artefacts, fiction films, music, and social 
media (Broberg, 2017). ${ }^{2}$ Drawing on Broberg's article, these materials can be roughly divided into two categories. The first category consists of materials meant to teach facts about religion (textbooks, images, sacred texts, artefacts, music), and the second category consists of materials meant to link religion and RE to the wider society (documentaries, television news, news articles, social media). Similar lines of reasoning can be found in another study, which concluded that one of the main motivations for teachers to use various news media was to link the content of their teaching to the wider society, often in order to show the relevance of religion and RE (Toft \& Broberg, 2018). ${ }^{3}$

This brings us to another aspect of why media literacy is so important for students and teachers alike. In Sweden, young peoples' encounters with religion mainly occur in school and through the media (e.g. Minnaar-Kuiper \& Trost, 2017; Klingenberg and Lövheim, 2019; Löfstedt and Sjöborg, 2019). Several studies concerning the visibility of religion in news media and public debates have concluded that religion is highly present in daily news flows (e.g. Bergdahl, 2010; Furseth, 2018; Lundby, 2018). Other studies have explored how religious issues appear in different kinds of popular culture (Löfstedt, 2011; Carlsson \& Thalén, 2015, Sjö, 2019) and how film and TV series have become important resources for people's search for existential meaning (Lövheim, Axelsson, \& Axner 2015). Frequently discussed in relation to this is the tendency of news media, but also film and TV series, to frame Islam and Muslims as violent and intimidating (Axner, 2015; for a meta-analysis of studies on Muslims and Islam since 2000, see Ahmed \& Matthes, 2017), and in her study Youth, Religion and Diversity, Marie von der Lippe claims that media have a great impact on how young people, in this case in Norway, talk about Islam and Muslims in relation to violence and terrorism (von der Lippe, 2011).

These tendencies within various media to structure and frame religion according to certain affordances, combined with the fact that such media materials and discourses are so present in RE classrooms, is the reason this article seeks to expand the conception of media literacy within RE research. By employing Meyrowitz's conceptualization of multiple media literacies, the article can highlight differences in how teachers and students view and engage with these kinds of media.

2 Worth noting here is that only about ten percent of the teachers reported using social media in their teaching 'always' or 'often'. This may seem contradictory, since the material of this study is full of teachers talking about how present social media is in their teaching. It is, however, quite possible for teachers to include, and critically reflect on, social media materials in the classroom without them viewing said social media as the 'material' of their lessons.

3 Conducted within the CoMRel project, see https://www.hf.uio.no/imk/english/research/projects/comrel/ for more information. 


\section{Methods and Material}

The material used in this study is derived from two separate but closely related projects. ${ }^{4}$ Thus, the material analysed in this article was not collected for the purpose of this specific study but consists of a purposeful sample of materials from both projects. The selection was based on the striking similarities in the themes identified in both projects. Below the respective processes of gathering and analysis of the materials will be described.

The teachers in this study were observed and interviewed within the framework of the TRILS project, which concerned RE teachers' professional role in general, with the potential influence of media on RE teachers' practice being one of many aspects the project sought to explore. ${ }^{5}$ Through semi-structured interviews, 22 teachers were asked questions about how they and their students relate to various media in an RE context. The transcribed interviews were thematically coded (Ryan \& Bernard, 2003) using the qualitative coding software NVivo.

The students were participating in a study conducted by Wrammert (forthcoming) with the purpose to explore upper secondary students' experiences of encounters with religion in various media and other social settings. ${ }^{6}$ Though the students participated in text writing and individual interviews, the material selected for this study consists only of the focus group interviews, which focused on the students' experiences of encounters with religion in different media. The focus group interviews were analysed using a constructionist thematic coding analysis (Brown \& Clarke 2006), again by use of NVivo.

Thus, the combined material consists of a total of 22 teachers and 37 students. More specifically, the sections from the transcribed materials that have been thematically coded as 'media literacy' or 'students' media awareness' (in the case of the teachers) and 'media awareness and resistance ${ }^{77}$ (in the case of the students) have been selected for further analysis in this article.

The research design is similar to what Robert Stake (2006) refers to as multiple case research, where several cases (in this case two) are used to explore a particular question (or the Quintin, as Stake phrases it). In line with Stake (1995, 2006), we argue that this form of data source triangulation embraces the fact that knowledge is socially constructed and context-specific, and in using different sets of data we get the opportunity to shed light on our Quintin from several perspectives, rather than just one. So while the teachers and students have not been asked exactly the same questions, their answers and reflections can still give insights from two quite different points of view.

4 The projects are closely related in terms of aims and theoretical framework. The materials have however not been gathered at the same schools, and are thus not directly related.

5 This material was collected by the TRILS project during 2016. PhD student Maximilian Broberg, as well as researchers Malin Löfstedt and Anders Sjöborg were part of the project.

6 This material was collected during 2018 by PhD student Anna Wrammert, as part of her PhD project.

7 This was one of four major themes identified in the student-material by Wrammert (forthcoming). 
A few words on the reasoning behind this choice of material. While our primary theoretical inquiry concerns media literacy, the setting we are interested in analysing is Swedish RE. As the dynamic relationship between teachers and students in the classroom is a constituting aspect of RE, it is not simply the students' media literacy that is of interest, but also the extent to which the teachers recognize that literacy, and to which degree students and teachers' media values are compatible. This is also the reason why such a specific conceptualization of media literacy (Meyrowitz 1998) has been selected for the analysis. We want to be able to discern where and how potential discrepancies between teachers' and students' media literacy occur.

\section{Media Literacy}

Media and communications scholar James Potter defines media literacy as 'a set of perspectives that we actively use to expose ourselves to the mass media to process and interpret the meaning of the messages we encounter' (Potter, 2016, p. 24). Potter further argues that one of the main characteristics of media literacy is that it is multidimensional $(2016$, p. 25). What this means is that when we think about information in for example textbooks and newspapers, we typically think of what he labels as cognitive information. These are dates, names, definitions and so on. However, we also have to consider that there are emotional, aesthetic and moral dimensions to most kinds of information. Thus, literacy in this sense is not just the ability to understand a text, but to realize that embedded in the text are things that can make us happy or sad, are beautiful or ugly, or that feel wrong or right. The ability to decipher text in this way is according to Potter not something you have or have not, rather, literacy should be viewed as a continuum.

There are various ways to analytically structure the multidimensionality Potter identifies as central to media literacy. In this article a conceptualization presented by Joshua Meyrowitz in 1998 will be used, where he argues that there are at least three distinct ways in which we can conceptualize the media, and depending on the conceptualization, the competencies needed to understand the media vary (Meyrowitz 1998).

The first conception of media is the view of media as conduits, that is, as conveyors of information (Meyrowitz, 1998, pp. 96-99). This view presupposes the possibility to separate media content from its medium, that media is a sort of intermediary between message and receiver. The competencies needed to critically engage with media content is conceptualized as media content literacy and manifests in the ability to understand, decode and categorize media content in various ways. The explicit and implicit messages in a text, the understanding of the institutional or cultural forces behind a message, and awareness of the fact that different groups in society are likely to read the same text in different ways are 
all part of media content literacy. Content elements tend to stay more or less the same, regardless of media format. For example, routine reporting about civilian casualties in a war will not change dramatically depending on the medium that happens to be the conduit for the information.

The second conception of media proposed by Meyrowitz is to view each medium as a specific language, with its own particular grammar (1998, pp. 99-103). The literacy needed to navigate this, media grammar literacy, focuses on the awareness and understanding of the specific production variables ${ }^{8}$ of various media, and how these are part of what shapes the receiver's perception and response to mediated communication. To give a few examples, print media can use different fonts or paper texture; television/film media can use close-ups or suggestive cuts, and various social media platforms will often make sure that content you tend to interact with appears more frequently. Although specific to the respective medium, these 'production variables' are ways to alter the perception of content. Ironically, media grammar elements are perhaps most powerful when the audience is not aware of them; if one does not realize that the shaky camera, the poor sound quality, and the crowded street are meant to give an authentic feel to a news flash, these grammar elements serve their purpose all the better. Thus, where media content is meant to be seen and heard, media grammar is ideally hidden, and consequently harder to spot.

Meyrowitz's final conception of media is that each medium is a specific environment with somewhat fixed characteristics, regardless of the content or grammar elements in play, and the awareness of this is conceptualized as medium literacy (1998, pp. 103-106). This form of literacy concerns the understanding of how the nature of a certain medium influences communication both on the micro- and macro-level. On the micro-level, this involves an understanding of how and why a certain medium may be preferable for a specific task. Looking for a job, making friends, ending an intimate relationship, or negotiating a peace treaty might turn out differently depending on the medium used (phone, e-mail, face-to-face and so on). On a macro, societal level, medium literacy would be the understanding of, for example, how the addition of a certain medium to the media matrix 'may alter the boundaries and nature of many social situations, reshape the relationships among people, and strengthen or weaken various social institutions' (Meyrowitz, 1998, p. 105). For example, the rise of social media may have challenged social conceptions of what it means to be educated or competent.

This concludes the three-pronged conceptualization of multiple media literacy. Before proceeding onto how these concepts were operationalized for the analysis,

8 This can also be framed as the aesthetics of a medium, which has much in common with the aesthetics Potter is referring to when discussing media multidimensionality above. Put differently, it is not the uniqueness of Meyrowitz's conceptualization that makes it interesting, but rather how well it fits with other research on media literacy. 
a few caveats are in order. First, we recognize that Meyrowitz's conceptualization is over 20 years old, and that much has happened, both technologically and theoretically, since the time it was written. Technologically, in 1998 the iPod had barely reached the market, and Social Network Sites (SNSs) were just emerging. Theoretically, this means that the kind of media Meyrowitz refers to is various forms of print, broadcasting or other audio-visual media, which actors primarily consume, not produce. While the same logic applies to some aspects of social media (different SNSs have different affordances or grammar one has to grasp in order to master them), the fact that the use of social media often means engagement with a wider social world, actor to actor, is largely missing from Meyrowitz's theory (cf. Livingstone, 2014 for an elaboration on social media literacy). Second, we also recognize that theories on media literacy such as the one employed in this study, at least implicitly, indicate that media literacy is a, if not the only, solution to a variety of media-related problems, ranging from cyberbullying to fake news. Media scholar danah boyd $(2014,2017)$ has even discussed the possibility of media literacy backfiring in the sense that we tend to overestimate the positive effects of typical media literacy mantras such as 'checking sources' or 'tracing the money'.

These critiques of our chosen conceptualization notwithstanding, we argue that multiple media literacy, largely because of its notion of medium literacy, is well suited as a point of departure for studying media literacy in our materials. We will, however, return to the thoughts of Livingstone and boyd in our concluding discussion in order to problematize our results.

\section{Model of Analysis}

Based on Meyrowitz's concept of multiple media literacy, the three types of literacy presented above are used to guide the analysis of the material. For each concept, a question has been formulated related to the materials, where the differences between the two studied groups are in focus.

\section{Media Content Literacy}

In what ways do teachers and students differ regarding their awareness of how media content can be understood, categorized, and decoded in various ways? This includes, for example, mentions and/or reflections on the credibility, motives, effects, or possible perception of a hypothetical or actual media content element.

\section{Media Grammar Literacy}

In what ways do teachers and students differ in their awareness of the 'production variables' (Meyrowitz, 1998) of various mediums? How newspapers, radio and television/film have different ways of framing and shaping a certain content is 
central here. As discussed above, while Meyrowitz's article is from before the major breakthrough of social media, instances where teachers or students reflect on production variables or affordances of a particular SNS will still be viewed as an indication of media grammar literacy.

\title{
Medium Literacy
}

In what ways do teachers and students differ in their awareness of how the nature of a medium shapes communication on the individual as well as the societal level? Do the participants voice opinions about how certain media are more or less appropriate to use in certain contexts (micro-level medium literacy), or that certain media are more closely connected to processes of social and/or cultural change (macro-level medium literacy)?

\begin{abstract}
Analysis
The following section is divided into three parts, corresponding to Meyrowitz's three kinds of media literacy. For each of the three concepts, examples from the materials are used to illustrate how teachers and students' engagements with mediated religion differ.
\end{abstract}

\section{Media Content Literacy}

Following the model of analysis presented above, the guiding question for analysing media content literacy is 'in what ways teachers and students differ with regard to their awareness of how media content can be understood, categorized, and decoded in various ways?' This is something discussed extensively in our material. Teachers especially, but to a certain degree the students as well, tend to view media as conduits, as conveyors of content. Thus, when asked about mediated religion, it is primarily media content that is discussed.

It was clear that when the teachers were asked about mediated religion, their immediate association was usually how Islam is depicted, particularly in news media.

Teacher: There is not a lot of talk about Hindus [in the media] right now.

Interviewer: So it is different to teach about religion now than it was 10-15 years ago?

Teacher: Yes. Concerning Islam it is. Absolutely. (Lisa, lower secondary)

From a Swedish perspective, it is not surprising that Islam is the first thing that comes to mind. Islam is by far the largest minority religion in Sweden, and heated political debates on Muslim integration, as well as the 'war on terrorism', have contributed to a predominately negative media image of Islam and Muslims in Sweden (e.g. Axner, 2015). Hence, most of our material revolves around Islam 
specifically rather than religion in general. Below, one of the teachers talk about the effect mediated Islam has on her students:

I believe their prejudice about Islam definitely comes from the media. [...] And I don't want others to get the wrong picture about Islam either. I want to show them that the Islam we see on the news is not mainstream Islam. (Tuva, lower secondary)

There are however nuances to this statement within the material. When Regina, an upper secondary school teacher, is asked to reflect on whether the media image of Islam affects her teaching, she states that it certainly does and that there is no 'quick fix' to the 'deeply rooted prejudice' she sees in her classroom. On the other hand, the lack of a quick fix does not mean the cause is lost. Consider the following statement from Regina on the same topic:

There are competing discourses. Many Muslim [students] are eager to present Islam as a religion of peace.

Others will refer to the media image and highlight the prejudice, regardless of personal conviction. That mix often leads to interesting discussions. (Regina, upper secondary)

Thus, the teachers highlight the importance of students knowing that many of the established media discourses on religion, and particularly those on Islam, tend to frame religion as problematic and dangerous.

As Regina hints at, many students seem well aware of these media discourses, and this awareness is actually one of the most prominent categories in the theme 'media awareness and resistance' from the student materials. For example, Jonna, one of the students, states that 'media is, to a great extent, the underlying factor for islamophobia', a statement that is echoed by many of the students in the materials.

We can thus conclude that when it comes to media content literacy, the participating students and teachers seem able to distinguish between content that is peaceful or violent, realistic or unrealistic, and so on, and we see no real difference in how teachers and students in our materials view this media image of Islam.

However, embedded in this critical eye towards media content is the conception that social media content is, by its very nature, different from other kinds of media content. While this view is present among the students, it is primarily the teachers who express this interpretation. Upper secondary teacher Johan reflects on this:

[T]hey live in these media bubbles. 'Russia is sending 15.000 men to Syria'. 'Yes, where have you seen that?' I said. 'I saw it on ..., 'yes, on Facebook, but who was the poster?' So they don't read SvD or DN.'

They can't ... they can't be bothered to watch Aktuellt or Rapport. ${ }^{10}$ I mean ... It has to be fast and short.

9 Svenska Dagbladet (SvD) and Dagens Nyheter (DN) are two of the most respected morning papers in Sweden. 10 Aktuellt and Rapport are two of the main news programs on Swedish public service television. 
Analytically, the claim that the content of one medium is preferable to the content of another medium is on the border between media content literacy and media grammar literacy. Content can certainly be evaluated based on its source, and if the source is considered unreliable (most teachers in the material consider social media as unreliable), so is the content. However, specific reasons are seldom given as to why social media cannot be trusted. Rather, that a piece of content has been obtained through social media seems to say more about its trustworthiness than the regular criteria used to evaluate media content, at least in the eyes of the teachers. More on this in the next section.

\section{Media Grammar Literacy}

The analytical question here is 'in what ways teachers and students differ in their awareness of the production variables of various mediums?' Interestingly, very little in our materials relates to the production variables suggested by Meyrowitz (1998). When different mediums are discussed in relation to each other, it is the credibility that is in focus, not the characteristics of the specific medium in terms of the tools available to shape or angle media content ${ }^{11}$. Typically, students and teachers alike agree that social media is less reliable than, for example, morning papers, but the teachers are in general more categorical than the students are. Consider, as an example, a typical quote from the 'students' media awareness' theme:

It is a disaster In this class 9, I ask 'how many of you watch Aktuellt or Rapport every day?' No one. 'Well where do you get your news from?' 'Facebook', they say. 'Alright', I say, but can you trust all that? 'No', they say. (Carina, lower secondary)

A closer look at Carina's paraphrased dialogue between herself and her students will serve to demonstrate some of the finer nuances in how the teachers and students in this study relate to various media. Teachers view traditional news media as more credible than social media; their students are more likely to use social media than traditional media for getting their news ${ }^{12}$; and this may cause potential problems - although the students are, to a varying degree, aware of these very problems. The following reflections by one of the students, Emil, illustrates this awareness:

In social media ... with trolls and everything, the fact that it is so easy to spread a message and fake news

everywhere. [...] I think it is interesting to read information through social media but I try to question

11 This is thoroughly elaborated on in the individual interviews with the students (Wrammert forthcoming).

12 In Sweden, 35\% of the population report watching television news every day, while $27 \%$ report reading news via Facebook every day. Among 15-24 year olds, the corresponding numbers are 14\% and 43\% respectively (Nordicom - Sweden's Media Barometer, 2018). 
basically everything I can since, yes... some things just sound too incredible to be true but... some news, if you see that newspapers like $S v D$ or $D N$, have written about it, then I trust it.

Again, this is on the border between media content and media grammar literacy. Emil discusses some aspects of social media grammar, such as its speed, lack of regulation, the tendency towards sensationalism, and so on, but does not discuss why the established morning papers would be more reliable, only that they are and that he trusts them. Some teachers also scratch the surface of media grammar by statements about how Facebook content can be 'very angled in several strange ways', or that Instagram is characterized by 'fast reactions on various events'. While not necessarily untrue, 'angled in several strange ways' can hardly be said to characterize Facebook's media grammar, although 'fast reactions' could be considered typical for social media, compared to the more thoughtful nature of, say, weekly news magazines. The students are more nuanced in the sense that they also see many positive aspects of social media, but apart from snippets about social media being more interactive than traditional media, or that it has incredible reach, they do not seem to reflect much on the 'production variables' in the sense Meyrowitz formulates them. One thing the students do highlight that teachers do not is the distinction on social media between user-generated content and content that is shared or created, by what they consider as a reliable source. While teachers address for example Facebook as an unreliable source, the students are more nuanced, and what should be taken seriously and not is a matter of interpretation. One of the students discusses Twitter:

Yes, but like this, if I read on Twitter that "Islam sucks", maybe I shouldn't just, "well it sucks" (laughter).

I mean, maybe you should ... "ah ok, why does it suck?" And maybe I should go to another page than

Twitter, which is based on some journalistic source ... (Klara, student)

So, while Klara is clearly cautious about trusting what she reads on Twitter, it is not because it came from social media that she is sceptical, but rather that she does not know how trustworthy the source is, that she will pursue other sources to verify or falsify the tweet. Despite this, different mediums do not seem to be viewed as separate languages with specific grammar to the same extent as they are viewed as conduits for certain content.

\section{Medium Literacy}

The question of analysis here is in what ways teachers and students differ in their awareness of how the nature of a medium shapes communication on the individual as well as societal level?'

There is no particular discussion present in our materials about this on the 
individual level. This absence is in line with our previous observation which indicates that media generally equals content in our material, not the specifics of certain mediums.

There are, however, several examples in our materials that focus on the societal level of medium literacy, and there are some interesting differences between the students and the teachers. Some of the teachers focus on how the rise of social media has given them more competition in terms of where young people get their information about religion. Filip, an upper secondary teacher, discusses this:

\begin{abstract}
For example, many watch news from their homeland [...]. Yes, they get it through social media, from what people write on Facebook, and there they have, in their groups, contacts who comment on the news from other countries. [...] And then you have to, in some way, say that this is how it is presented in Sweden, and they ask "why do they bring this up, why is it presented in this way [in Sweden]?" And yes, that is quite tricky actually.
\end{abstract}

His role as the teacher is thus not only to supply their students with knowledge on religion but to provide the tools with which their students can navigate all these competing sources. They also feel that the availability, and the abovementioned 'fast reactions', of social media, have come to challenge the slower, more meticulous kinds of news media that they trust and are familiar with (see for example Johan's quote in the previous section). In this sense, the teachers are more pronounced in their promotion of caution towards new media than the students are, and see it as somewhat problematic that their students do not watch the evening news, or read morning papers.

The students, on the other hand, tend to view social media, and to some extent popular culture, as mediums that allow for a much higher grade of individualization and customization. They actively look for news and narratives they are interested in, and by doing so they give these sources authority. The student Noor is an example of this. The global nature of a medium such as Twitter is able to cater to her interest in 'human rights' questions in Libya, and the fact that she has not found any corresponding interest for these questions in Swedish national news coverage is the reason behind her following statement:

Somehow it feels like the school and 'old media' are not catching up with the paradigm shift. In a way, everything I have learned comes from Twitter. (Noor, student)

This is a key aspect of Meyrowitz's conceptualization of medium literacy. What does a particular medium bring, or change, when added to the media matrix? The teachers express a form of medium literacy in the sense that they realize that social media challenges their role as authorities, and places them in a situation 
where they, and their students, constantly need to grapple with an ever-growing number of sources of religious content. The students do perhaps not express medium literacy, but they certainly act in accordance with Meyrowitz's conceptualization of media as environments.

\section{Conclusion}

This study has illustrated how an expanded view of media literacy can be useful when exploring media influence in an RE context. By the use of Meyrowitz's concept of multiple media literacy (1998), we have shown that both the students and teachers in our materials seem to possess high levels of media content literacy, but are less familiar with media grammar and medium literacy. This indicates that, in RE classrooms, media is likely to be viewed as conduits, as carriers of content, rather than specific languages or environments.

The study has also identified a number of differences between the teachers and the students. These differences were most pronounced when it came to social media. The teachers are more categorical in their scepticism towards social media, while several of the students express a more nuanced view, for example by differentiating between user-generated content and content that is shared from established news sources. Furthermore, the teachers primarily view social media as a challenge, while the students are more likely to view it as an opportunity.

While we argue that media literacy is a necessary part of RE in mediatized societies, the results of this study can also illustrate the concept's limits. Several of the teachers display a form of uncritical criticism towards social media and are dismayed by their students' perceived naivety. From the students' perspective, this is closely linked to the argument by boyd (2017) who states that too many students she meets have been told that Wikipedia is unreliable and that they should do their own research instead, which is similar to how social media is viewed by the teachers in our material, who essentially de-legitimize social media as a source of information about religion. This constitutes an apparent risk of alienating the students who actually get their information about religion through social media, and it also presumes that by letting their students do 'their own research', or read an established morning paper, they can circumvent many of the perceived problems social media pose. Based on the results of this study, we argue that $\mathrm{RE}$ teachers would benefit from being more nuanced in their critique of social media and focus more on the grammar that makes a specific medium more or less suitable for various activities.

Previous research has addressed the fact that the diverse ways in which media come to co-structure the RE practice call for new competencies and concepts, for RE teachers, students, and researchers alike (e.g. Broberg 2019; Toft, 2019). Thus, while the materials analysed in this study is limited to a small number of teachers 
and students, the article has still illustrated how a development of the concept of media literacy can be one step in alleviating some of the potential problems an increased media presence brings to RE classrooms.

\section{REFERENCES}

Ahmed, S. \& Matthes, J. 2017. «Media representations of Muslims and Islam from 2000 to 2015. A meta-analysis.» International Communications Gazette, 79(3), 219-244.

Axner, M. 2015. Representationer, stereotyper och nyhetsvärdering; rapport frän medieanalys om representationer av muslimer $i$ svenska nyheter, Stockholm: Diskrimineringsombudsmannen.

Bergdahl, L. 2010. Seeing Otherwise. Renegotiating Religion and Democracy as Questions for Education. Ph.D. diss., Stockholms Universitet.

boyd, d. 2014. it's complicated. the social lives of networked teens. London: Yale University Press.

boyd, d. 2017. «Did Media Literacy Backfire?» Data and Society: Points [blog post, accessed April 16, 2019].

Broberg, M. 2017. "The Use of Teaching Materials in Religious Education in Sweden. A quantitative analysis of Swedish religious education teachers' reported use of teaching materials in RE classrooms.» British Journal of Religious Education. DOI: 10.1080/01416200.2017.1405795

Broberg, M. 2019. Stay Awhile and Listen. Understanding the dynamics of mediatization, authority and literacy in Swedish religious education. Ph.D. diss., Uppsala university.

Carlsson, D. \& Thalén, P., (red.). 2015. Det postsekulära klassrummet. Mot ett vidgat religionskunskapsbegrepp. Gävle: Högskolan i Gävle.

Furseth, I., (Ed.). 2018. Religious complexity in the public sphere. Comparing Nordic countries. Basingstoke: Palgrave Macmillan.

Jackson, R., Ipgrave, J., Hayward M., Hopkins, P., Fancourt, N., Robbins M., Francis, L. \& McKenna, U. 2010. Materials used to Teach about World Religions in Schools in England. Research Report DCSF-RR197. London: Department for Children, Families and Schools.

Jackson, R. 2017. Signposts - Policy and practice for teaching about religions and non-religious world views in intercultural education. Strasbourg: Council of Europe Publishing.

Klingenberg, M. \& Sjöborg, A. 2015. «Religion i ungas vardagsliv.» I M. Lövheim \& M. Nordin (Eds.), Sociologiska perspektiv på religion i Sverige (pp. 69-89). Malmö: Gleerups.

Klingenberg, M. \& Lövheim, M., (red.). 2019. Unga och religion: Troende, ointresserade eller neutrala. Malmö: Gleerups. 
Lied, L. I. \& Toft, A. 2018. «Let Me Entertain You.» I K. Lundby (Ed.), Contesting Religion: The Media Dynamics of Cultural Conflicts in Scandinavia (pp. 243-258). Boston: De Gruyter.

Lippe von der, M. 2011. «Reality Can Bite. Perspectives of Young People on the Role of Religion in Their World.» Nordidactica - Journal of Humanities and Social Science Education 1(2): 15-34.

Livingstone, S. 2014. «Developing social media literacy: How children learn to interpret risky opportunities on social network sites.» Communications 39(3): 283-303.

Lundby, K., (Ed.). 2018. Contesting Religion. The Media Dynamics of Cultural Conflicts in Scandinavia. Berlin and Boston: De Gruyter.

Löfstedt, M., (Ed.). 2011. Religionsdidaktik - mångfald, livsfrågor och etik $i$ skolan. Lund: Studentlitteratur.

Löfstedt, M., \& Sjöborg, A. 2019. «Unga, religion och lärande.» I M. Klingenberg \& M. Lövheim (Eds.), Unga och religion: Troende, ointresserade eller neutrala, (pp. 147-163). Malmö: Gleerups.

Lövheim, M. 2012. «Religious Socialization in a Media Age.» Nordic Journal of Religion and Society, 25(2): 151-168.

Lövheim, M., Axelsson, T. \& Axner, M. 2015. «Religion och medier.» I M. Lövheim \& M. Nordin (Eds.), Sociologiska perspektiv på religion i Sverige (pp. 143-160). Malmö: Gleerups.

McDougall, J., Sternadel, D., van Driel, B. and Zezulkova, M. 2018. «Teaching media literacy in Europe: evidence of effective school practices in primary and secondary education», NESET II report. Luxembourg: Publications Office of the European Union. doi: 10.2766/613204.

Meyrowitz, J. 1998. «Multiple media literacies.» Journal of Communication 48(1), 96-108.

Minnaar-Kuiper, E. \& Trost, G. B. 2017. «Dutch non-affiliated pre-vocational pupils, their world view and religious education.» British Journal of Religious Education. DOI: 10.1080/01416200.2017.1405796

Nygren, P. \& Bronéus, F. 2018. Slutrapport: Nyhetsvärderaren. Stockholm: Vetenskap \& Allmänhet.

Nordicom - The Swedish Media Barometer. (n.d.) Retrieved August 16, 2019, from https://www.nordicom.gu.se/en/media-barometer-2019

Potter, J. 2016. Media Literacy. (9th ed). Los Angeles: Sage.

Sjö, S. (2019). «Humor som bro eller hinder. Islam i två norska filmkomedier.» I P. K. Botvar, A. K. Gresaker \& O. Hovdelien (red.), Ingen spøk. En studie av religion og humor (s. 119-139). Oslo: Cappelen Damm Akademisk. https://doi.org/10.23865/noasp.69.ch6. 
Skolverket 2011. Curriculum for Compulsory School, Preschool Class and the Recreation Centre. Stockholm: Skolverket.

Stake, R. 1995. The Art of Case Study Research. London: Sage.

Stake, R. 2006. Multiple Case Study Analysis. New York: Guilford Publications.

Toft, A. \& Broberg, M. 2018. «Mediatized Religious Education.» I K. Lundby, Contesting Religion: The Media Dynamics of Cultural Conflicts in Scandinavia (pp. 225-242). Boston and Berlin: De Gruyter.

Toft, Audun. 2019. Conflict and Entertainment: Media Influence on Religious Education in Upper Secondary School in Norway. Ph.D. diss., Norwegian School of Theology, Religion and Society. 